\title{
Comparative petrology of the Hotaka and Akagi volcanoes
}

\author{
TAKASHI YAMAGUCHI \\ Earthquake Research Institute, University of \\ Tokyo, Yayoi, Bunkyo-ku 113, Japan \\ (present address: Mitsubishi Mining \& Cement Co., Ltd., 2270 Yokoze, \\ Chichibu-gun, Saitama-ken, 368, Japan)
}

\begin{abstract}
The path of fractional crystallization in the magma reservoir is different in the Akagi and Hotaka volcanoes, both of which are frontal volcanoes of northeastern Japan arc. Estimated magmatic temperature decreases by about $130^{\circ} \mathrm{C}$ from 1050 to $920^{\circ} \mathrm{C}$ during the compositional change of liquid from 54 to $70 \mathrm{wt} \% \mathrm{SiO}_{2}$ in the Akagi volcano. In the Hotaka volcano, however, the temperature decreases by only about $60^{\circ} \mathrm{C}$ from 1050 to $990^{\circ} \mathrm{C}$ during the same compositional change. This difference is also reflected on the early appearance of hornblende and common occurrence of groundmass hypersthene in the Akagi volcano. $\mathrm{Al}_{2} \mathrm{O}_{3}$ content of the magma of the Akagi volcano is higher than that of the Hotaka volcano. These differences can be well accounted for by the different water contents in the parental magmas; the magma of the Akagi volcano had a higher water content.

They also show different chemical trends on $\mathrm{FeO}^{*} / \mathrm{MgO}-\mathrm{SiO}_{2}$ variation diagram; the constant $\mathrm{FeO} / \mathrm{MgO}$ ratio with increasing $\mathrm{SiO}_{2}$ in the Akagi volcano in contrast to the iron-enrichment trend in the Hotaka volcano. Least-squares mixing calculations show that the different iron-enrichment is caused by the different proportions of plagioclase in the fractionated minerals ; higher plagioclase proportion in the Akagi magma than in the Hotaka magma.
\end{abstract}

\section{Introdution}

Fractional crystallization is regarded as one of the major processes generating the chemical and mineralogical variations of volcanic rocks in island arc (e.g., Gill ,1981). Fractional crystallization is primarily caused by the temperature decrease of the magma. Compositional change of the liquid (liquid line of descent) and crystallization sequence along with the temperature decrease must be different in different parental magmas, depending on their major chemical compositions including water. Sakuyama (1983) recognized three different crystallization sequences in the northeastern Japan arc magmas, and attributed the variation essentially to the different water content in the parental magmas. His consideration, however, was concentrated on the crystallization sequences. The compositional change of liquid must be examined at the same time.

The purpose of this paper is 1) to clarify the relationship between the liquid line of descent and crystallization sequence of the magma of the Akagi volcano with special reference to their relationship to the magmatic temperature and 2) to compare them with already published data of the Hotaka volcano (Yamaguchi, 1984) in order to recognize the possible effect of water on the fractional crystallization process.

Both Akagi and Hotaka volcanoes are Quaternary composite volcanoes in the south-

(Manuscript received, March 22, 1990; accepted for publication, April 13, 1990) 


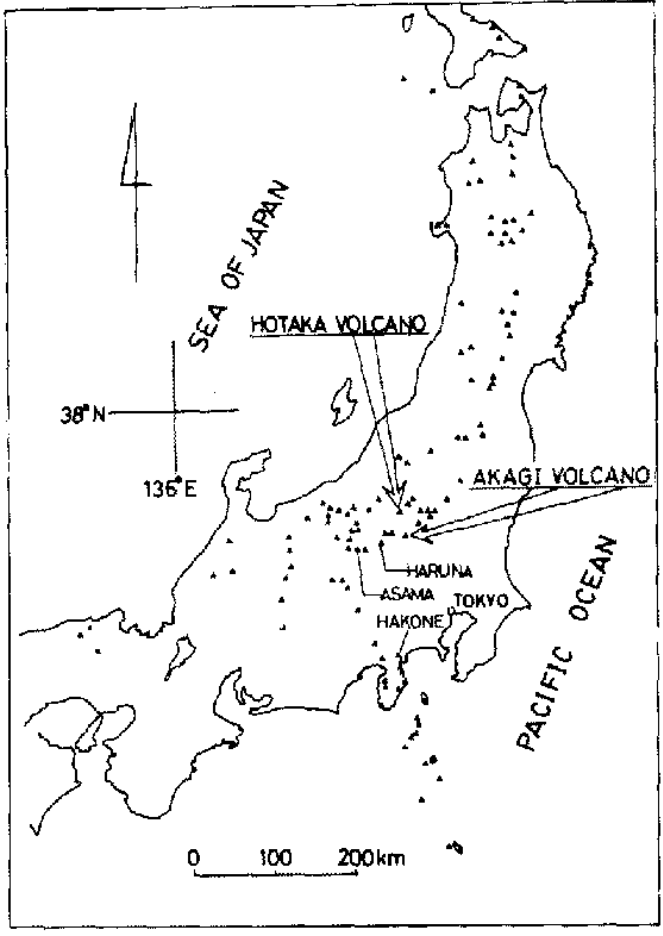

Fig. 1. Index map of Hotaka and Akagi volcanoes. Solid triangles represent the Quaternary volcanic centers.

ernmost part of the Nasu volcanic zone, along the volcanic front of northeastern Japan (Fig. 1).

Geology and petrography of the Akagi volcano were described by Ota $(1952,1953)$, Moriya (1968, 1970) and Koga (1984). According to Moriya (1970), the geologic history is divided into three stages; the older stratovol. cano, the younger stratovolcano and the central cone. The older stratovolcano consists of lavas and pyroclastic rocks. It was deeply eroded before the stage of the younger stratovolcano. Pyroclastic fall and flow deposits construct the younger stratovolcano. The small caldera, 2 to $4 \mathrm{~km}$ across, was formed at the summit before the third stage. In the third stage $(20,000-30,000$ years before present) essential fragments were ejected as pyroclastic falls and two lava domes were formed.

Geology of Hotaka volcano was reported by Yamaguchi (1981). The Hotaka volcano has not been active since the later Pleistocene. The early stage of the volcanic activity was mainly characterized by scoria falls and scoria flows and lava flows became predominent in the later stage. The horseshoe-shaped erosion caldera, $1.5 \mathrm{~km}$ across, was formed in the central part of the volcano.

\section{Brief Summary of petrography of Hotaka volcano}

Detailed petrography was reported by Yamaguchi (1984). Summary of the study is given in this paper. Aphyric and porphyritic andesites and dacites $\left(53.5\right.$ to $\left.68 \mathrm{wt} \% \quad \mathrm{SiO}_{2}\right)$ occur in the Hotaka volcano. A well defined liquid line of descent was obtained from the chemical compositions of the aphyric rocks and it was supplemented by calculated groundmass compositions of the porphyritic rocks.

Mineral assemblage and chemical compositions of phenocrysts change systematically with the change of the chemical composition of the groundmass. $\mathrm{Mg} / \mathrm{Fe}+\mathrm{Mg}$ mole ratio of hyper. sthene phenocrysts ranges from 0.72 to 0.55 and Wo content ranges from 4 to 2.8 mole\%. $\mathrm{Mg} /$ $\mathrm{Fe}+\mathrm{Mg}$ mole ratio of augite phenocrysts ranges from 0.75 to 0.6 . Wo content of augite is 39 to $43 \%$. An content of plagioclase phenocrysts ranges from 98 to 50 mole\%. Although An content of cores of phenocrysts varies in the range 45 mole\% at maximum within a single rock specimen, averaged An content decreases from 90 to 55 with increasing $\mathrm{SiO}_{2}$ content of the groundmass.

The crystallization sequence in the magma reservoir could be known by the relationship of phenocryst assemblages and groundmass $\mathrm{SiO}_{2}$ contents. The crystallization sequence with increasing $\mathrm{SiO}_{2}$ content of the groundmass is as follows (Fig. 4). Olivine, hypersthene, augite, plagioclase and magnetite coexist in the liquid whose $\mathrm{SiO}_{2}$ content ranges from 53.5 to $56 \mathrm{wt} \%$. 
In the liquid with more than $57 \mathrm{wt} \% \mathrm{SiO}_{2}$ content, olivine disappears or is surrounded by thick hypersthene reaction $\operatorname{rim}(0.2$ to $1 \mathrm{~mm}$ in width). Augite, hypersthene, magnetite and plagioclase continuously crystallize until the $\mathrm{SiO}_{2}$ content of liquid attains at least $70 \mathrm{wt} \%$. Ilmenite phenocrysts appear in the rocks whose $\mathrm{SiO}_{2}$ contents of groundmass are more than about $70 \mathrm{wt} \%$.

The assemblage of groundmass pyroxenes changes with increasing groundmass $\mathrm{SiO}_{2}$ content in the following order: augite + pigeonite $\rightarrow$ pigeonite $\rightarrow$ pigeonite + hypersthene $\rightarrow$ hypersthene. Even when only hypersthene occurs in the groundmass, fine-grained pigeonite surrounds augite phenocrysts. The chemical and mineralogical feature of fractional crystallization is close to that of other island arc tholeites in Japan.

\section{Petrology of Akagi volcano}

\section{Petrography}

The rocks of the Akagi volcano are basalt, andesite and dacite. Modal compositions and groundmass pyroxene assemblages are shown in Table 1. Total phenocryst content ranges from 13 to 43 vol\%. Five rock types are distinguished based on mafic phenocryst assemblages and groundmass pyroxene assemblages as shown in Table 2.

The phenocrysts of the type 1 rocks are olivine, augite, hypersthene, plagioclase and magnetite. The groundmass contains pigeonite with or without augite. OS3 shows slightly different petrographic features; that is, it contains pigeonite microphenocrysts without augite phenocrysts. But it is assigned to the type 1 because of presence of olivine pheno. crysts and the similar $\mathrm{SiO}_{2}$ content to OS1 and OS2.

The phenocrysts of the type 2 rocks are augite, hypersthene, plagioclase and magnetite. Abundance of augite phenocrysts is characteris- tically small, less than 1 vol\%. OS 8 does not contain augite phenocrysts. The groundmass pyroxene is pigeonite with or without augite and hypersthene. Groundmass hypersthene is very small in abundance if it is present. OS4 contains a small amount of microphenocryst of pigeonite.

The phenocrysts of the type 3 rocks are augite, hypersthene, plagioclase and magnetite. Augite and hypersthene occur also as ground. mass constituents in contrast to the type 2 rocks.

The phenocrysts of the type 4 rocks are augite, hypesthene, hornblende, plagioclase, magnetite and ilmenite. The groundmass pyroxenes are augite and hypersthene except OS14 which does not contain groundmass augite. A considerable amount of glass is present in the groundmass.

The phenocrysts of the type 5 rocks are hypersthene, hornblende, plagioclase, magnetite and ilmenite. Groundmass hypersthene sparsely occurs in the glassy matrix.

The older stratovolcano is mainly composed of the rocks of the type 1 and 2 with rare type 3 and 4 rocks. The younger stratovolcano mainly consists of the rocks of type 4 . The lava domes and essential fragments in the air fall deposits in the stage of central cone are type 5 rocks.

Chemical compositions of rocks and groundmass

Whole-rock major chemical compositions were determined by X-ray fluorescence analysis using fused disc samples. Datails of the analytical method were described by Matsumoto and Urabe (1980). Groundmass chemical compositions were estimated from the whole-rock chemical compositions by subtracting the chemical compositions of the phenocryst minerals according to the modal compositions expressed in weight percent. The chemical compositions of whole-rock and ground- 
Table 1. Modal compositions

Phenocryst

\begin{tabular}{|c|c|c|c|c|c|c|c|c|c|c|c|c|c|}
\hline & & 01 & Hyp & Aug & Pig & Ho & $M t$ & I 1 & Plg & & Pig & Aug & Hyp \\
\hline Type1 & $\begin{array}{l}\text { os } 1 \\
\text { os } 2 \\
\text { os } 3\end{array}$ & $\begin{array}{l}0.7 \\
0.4 \\
\text { tr. }\end{array}$ & $\begin{array}{l}5.5 \\
4.9 \\
0.5\end{array}$ & $\begin{array}{c}0.8 \\
0.6 \\
-\end{array}$ & $\begin{array}{c}- \\
2.2\end{array}$ & $\begin{array}{l}- \\
- \\
-\end{array}$ & $\begin{array}{l}1.6 \\
1.6 \\
0.7\end{array}$ & $\begin{array}{l}- \\
- \\
-\end{array}$ & $\begin{array}{l}24.4 \\
23.2 \\
27.8\end{array}$ & $\begin{array}{l}67.0 \\
69.3 \\
68.8\end{array}$ & $\begin{array}{l}0 \\
0 \\
0\end{array}$ & $\begin{array}{l}0 \\
0\end{array}$ & $\begin{array}{l}- \\
- \\
-\end{array}$ \\
\hline Type2 & $\begin{array}{ll}\text { OS } & 4 \\
\text { OS } & 5 \\
\text { os } & 6 \\
\text { OS } 7 \\
\text { OS } 8 \\
\text { os } 9 \\
\text { os } 10\end{array}$ & $\begin{array}{l}- \\
- \\
- \\
- \\
- \\
- \\
-\end{array}$ & $\begin{array}{l}1.0 \\
7.4 \\
9.4 \\
8.3 \\
9.6 \\
8.1 \\
9.4\end{array}$ & $\begin{array}{c}0.8 \\
0.4 \\
\text { tr. } \\
1.0 \\
- \\
0.9 \\
0.4\end{array}$ & $\begin{array}{c}\text { tr. } \\
- \\
- \\
- \\
- \\
- \\
-\end{array}$ & $\begin{array}{l}- \\
- \\
- \\
- \\
- \\
-\end{array}$ & $\begin{array}{l}0.3 \\
1.0 \\
1.7 \\
1.7 \\
1.0 \\
1.6 \\
2.0\end{array}$ & $\begin{array}{l}- \\
- \\
- \\
- \\
- \\
- \\
-\end{array}$ & $\begin{array}{l}25.8 \\
30.8 \\
31.8 \\
31.9 \\
31.3 \\
24.4 \\
22.1\end{array}$ & $\begin{array}{l}72.1 \\
60.4 \\
57.1 \\
57.1 \\
58.1 \\
65.0 \\
66.1\end{array}$ & $\begin{array}{l}0 \\
0 \\
0 \\
0 \\
0 \\
0 \\
0\end{array}$ & $\begin{array}{l}- \\
0 \\
0 \\
0 \\
- \\
- \\
0\end{array}$ & $\begin{array}{l}- \\
0 \\
- \\
- \\
- \\
0\end{array}$ \\
\hline Type 3 & $\begin{array}{l}\operatorname{os} 12 \\
\operatorname{os} 13\end{array}$ & - & $\begin{array}{r}7.0 \\
.5 .4\end{array}$ & $\begin{array}{l}0.2 \\
0.5\end{array}$ & - & - & $\begin{array}{l}0.9 \\
0.9\end{array}$ & - & $\begin{array}{l}29.7 \\
19.1\end{array}$ & $\begin{array}{l}62.2 \\
74.1\end{array}$ & - & $\begin{array}{l}0 \\
0\end{array}$ & $\begin{array}{l}0 \\
0\end{array}$ \\
\hline Type 4 & $\begin{array}{l}\text { OS1 } 4 \\
\text { OS15 } \\
\text { YS } 1 \\
\text { XS } 2 \\
\text { XS } 3\end{array}$ & $\begin{array}{l}- \\
- \\
- \\
-\end{array}$ & $\begin{array}{l}3.8 \\
7.5 \\
5.4 \\
6.3 \\
5.3\end{array}$ & $\begin{array}{l}0.3 \\
1.7 \\
2.3 \\
2.6 \\
1.2\end{array}$ & $\begin{array}{l}- \\
- \\
- \\
- \\
-\end{array}$ & $\begin{array}{l}\text { tr. } \\
\text { tr. } \\
\text { tr. } \\
0.1 \\
\text { tr. }\end{array}$ & & $\begin{array}{l}1.0 \star \\
2.0 \star \\
1.8 \star \\
2.0 \star \\
1.4 \star\end{array}$ & $\begin{array}{l}18.1 \\
21.8 \\
27.2 \\
26.1 \\
21.9\end{array}$ & $\begin{array}{l}76.8 \\
67.0 \\
63.3 \\
62.9 \\
70.2\end{array}$ & $\begin{array}{l}- \\
- \\
- \\
- \\
?\end{array}$ & $\begin{array}{l}- \\
0 \\
0 \\
0 \\
2\end{array}$ & $\begin{array}{l}0 \\
0 \\
0 \\
0 \\
?\end{array}$ \\
\hline Types & $\begin{array}{ll}\mathrm{CC} & 1 \\
\mathrm{CC} & 2\end{array}$ & - & $\begin{array}{l}0.5 \\
0.2\end{array}$ & - & - & $\begin{array}{l}1.2 \\
0.7\end{array}$ & & $\begin{array}{l}0.6 * \\
0.4 *\end{array}$ & $\begin{array}{l}13.4 \\
12.1\end{array}$ & $\begin{array}{l}84.3 \\
86.6\end{array}$ & - & - & 0 \\
\hline
\end{tabular}

- Both magnetite and ilmenite phenocrysts are present but only total amounts of the opaque minerals were measured. Except in the Type 5 rocks the amounts of magnetite phenocrysts are greater than those of ilmenite phenocrysts.

Gm, Groundmass; Py, Pyroxene; Ol, Olivine; Hyp, Hypersthene ; Aug, Augite; Pig, Pigeonite; Ho, Hornblende; Mt, Magnetite; Il, Ilmenite; Plg, Plagioclase

OS1, basalt lava

OS2, basait lava

OS3, basalt lava

OS4, andesite lava

OS5, andesite lava

OS6, andesite lava

OS7, andesite lava

OS8, andesite lava

OS9, andesite lava

OS10, andesite lava

(OS11, andesite pyroclastic fall deposit)

O\$12, andesite lava

$\mathrm{O} \$ 13$, andesite lava

OS14, andesite dike

OS15, andesite pyroclastic fow deposit

YS1, andesite pyroclastic flow deposit

YS2, andesite pyroclastic flow deposit

YS3, andesite pyroclastic flow deposit

$\mathrm{CCl}$, dacite pyroclastic fall deposit

$\mathrm{CC} 2$, dacite pyroclastic fall deposit

OS, older stratovolcano YS, younger stratovolcano

$\mathrm{CC}$, central cone

Table 2. Rock types

\begin{tabular}{ccr} 
Type & Phenocryst & Groundmass \\
\hline 1 & ol + hyp $+($ aug $)$ & plg $+($ aug $)$ \\
2 & hyp $+($ aug $)$ & pig $+($ aug $)+($ hyp $)$ \\
3 & hyp + aug & aug + hyp \\
4 & ho + hyp + aug & $($ aug $)+$ hyp \\
5 & ho + hyp & hyp \\
\hline
\end{tabular}

ol, olivine; hyp, hypersthene; aug, augite; ho, hornblende; pig, pigeonite mass are shown in Tables 3 and 4 respectively. The whole-rock $\mathrm{SiO}_{2}$ contents range from 51 wt\% to $70 \mathrm{wt} \%$ and those of the groundmass range from 54 to $76 \mathrm{wt} \%$. The $\mathrm{SiO}_{2}$ contents of the whole-rock successively increase from the type 1 to the type 5 rocks; 51 to $52 \mathrm{wt} \%$ for the type 1 rocks, 54 to $58 \mathrm{wt} \%$ for the type 2 and 3 rocks, 56 to 61 wt\% for the type 4 rocks, about $70 \mathrm{wt} \%$ for the type 5 rocks. The 
Table 3. Chemical compositions of whole rocks

\begin{tabular}{lrrrrrrrrrr}
\hline & OS 1 & OS 2 & OS 3 & OS 4 & OS 5 & OS 6 & OS 7 & OS 8 & OS 9 & OS 10 \\
\hline $\mathrm{SiO}_{2}$ & 51.25 & 51.31 & 51.21 & 57.73 & 54.16 & 53.75 & 53.60 & 53.90 & 56.39 & 56.21 \\
$\mathrm{TiO}_{2}$ & 0.77 & 0.79 & 0.77 & 0.63 & 0.77 & 0.80 & 0.85 & 0.79 & 0.75 & 0.75 \\
$\mathrm{Ml}_{2} \mathrm{O}_{3}$ & 20.69 & 19.92 & 22.14 & 20.52 & 20.12 & 19.76 & 19.03 & 19.42 & 19.27 & 19.21 \\
$\mathrm{Fe}_{2} \mathrm{O}_{3} *$ & 9.95 & 9.84 & 8.72 & 6.22 & 9.59 & 10.06 & 9.77 & 9.81 & 8.98 & 9.04 \\
$\mathrm{HOO}^{2}$ & 0.20 & 0.17 & 0.15 & 0.11 & 0.14 & 0.16 & 0.15 & 0.17 & 0.17 & 0.14 \\
$\mathrm{MgO}$ & 5.03 & 4.84 & 3.11 & 2.10 & 4.58 & 4.86 & 4.27 & 4.69 & 3.83 & 4.07 \\
$\mathrm{CaO}$ & 10.09 & 9.84 & 10.45 & 7.96 & 8.84 & 8.65 & 8.56 & 8.52 & 7.65 & 8.02 \\
$\mathrm{Na}_{2} \mathrm{O}$ & 1.69 & 2.10 & 2.28 & 3.03 & 1.95 & 2.19 & 2.35 & 2.54 & 2.42 & 2.19 \\
$\mathrm{~K}_{2} \mathrm{O}$ & 0.24 & 0.27 & 0.28 & 0.84 & 0.39 & 0.39 & 0.46 & 0.38 & 0.70 & 0.66 \\
$\mathrm{P}_{2} \mathrm{O}_{5}$ & 0.04 & 0.10 & 0.09 & 0.16 & 0.06 & 0.10 & 0.13 & 0.11 & 0.06 & 0.07 \\
$\mathrm{Total}$ & 99.95 & 99.18 & 99.20 & 99.30 & 100.60 & 100.72 & 99.17 & 100.33 & 100.22 & 100.36 \\
\hline
\end{tabular}

OS 11 OS 12 OS 13 OS 14 OS 15 YS 1 YS 2 YS $3 \quad$ CC $1 \quad$ CC 2

\begin{tabular}{lrrrrrrrrrr}
\hline $\mathrm{SiO}_{2}$ & 56.80 & 57.14 & 55.98 & 55.82 & 60.58 & 59.14 & 58.43 & 60.96 & 70.41 & 69.85 \\
$\mathrm{NiO}_{2}$ & 0.63 & 0.67 & 0.74 & 0.73 & 0.66 & 0.69 & 0.70 & 0.54 & 0.30 & 0.30 \\
$\mathrm{AL}_{2} \mathrm{O}_{3}$ & 20.77 & 18.44 & 18.99 & 18.84 & 18.48 & 19.54 & 18.53 & 18.76 & 16.05 & 15.77 \\
$\mathrm{Fe}_{2} \mathrm{O}_{3}$ & 6.27 & 8.04 & 9.02 & 8.69 & 7.32 & 7.53 & 7.72 & 5.78 & 2.63 & 2.56 \\
$\mathrm{MnO}$ & 0.10 & 0.15 & 0.14 & 0.13 & 0.12 & 0.11 & 0.12 & 0.10 & 0.03 & 0.07 \\
$\mathrm{MgO}$ & 2.00 & 3.33 & 4.13 & 3.77 & 3.19 & 3.31 & 3.41 & 2.64 & 0.82 & 0.86 \\
$\mathrm{CaO}$ & 7.61 & 7.12 & 7.46 & 7.69 & 6.70 & 7.29 & 6.62 & 5.51 & 3.58 & 3.32 \\
$\mathrm{Na}_{2} \mathrm{O}$ & 2.68 & 2.58 & 2.72 & 2.53 & 2.61 & 2.24 & 2.70 & 2.86 & 2.96 & 3.40 \\
$\mathrm{~K}_{2} \mathrm{O}$ & 0.84 & 0.70 & 0.68 & 0.67 & 1.02 & 0.74 & 0.87 & 1.02 & 1.89 & 1.93 \\
$\mathrm{P}_{2} \mathrm{O}_{5}$ & 0.12 & 0.14 & 0.13 & 0.15 & 0.05 & 0.05 & 0.10 & 0.10 & 0.03 & 0.07 \\
Total & 97.82 & 98.31 & 99.99 & 99.02 & 100.72 & 100.64 & 99.20 & 98.27 & 98.70 & 98.13 \\
\hline
\end{tabular}

Table 4. Chemical compositions of groundmass

\begin{tabular}{lcccccccccc}
\hline & OS 1 & OS 2 & OS 3 & OS 4 & OS 5 & OS 6 & OS 7 & OS 8 & OS 9 & OS 10 \\
\hline $\mathrm{SiO}_{2}$ & 55.4 & 55.9 & 54.2 & 62.6 & 58.1 & 59.0 & 59.5 & 57.6 & 62.4 & 62.1 \\
$\mathrm{TiO}_{2}$ & 0.63 & 0.64 & 0.90 & 0.78 & 0.89 & 0.74 & 0.83 & 0.99 & 0.60 & 0.48 \\
$\mathrm{Al}_{2} \mathrm{O}_{3}$ & 18.9 & 18.0 & 19.2 & 16.7 & 17.2 & 17.1 & 16.6 & 16.7 & 18.1 & 18.8 \\
$\mathrm{Fe}_{2} \mathrm{O}_{3}$ & 9.22 & 9.10 & 10.2 & 7.61 & 10.2 & 9.05 & 9.17 & 10.5 & 6.74 & 5.84 \\
$\mathrm{MnO}$ & 0.24 & 0.19 & 0.18 & 0.14 & 0.15 & 0.17 & 0.15 & 0.19 & 0.17 & 0.11 \\
$\mathrm{MgO}$ & 4.41 & 4.56 & 3.67 & 2.35 & 4.07 & 3.91 & 3.28 & 3.35 & 2.18 & 2.01 \\
$\mathrm{CaO}$ & 8.53 & 8.37 & 8.56 & 4.94 & 6.75 & 6.71 & 6.99 & 7.00 & 5.79 & 6.99 \\
$\mathrm{Na}_{2} \mathrm{O}$ & 2.17 & 2.71 & 2.54 & 3.51 & 1.98 & 2.51 & 2.58 & 2.84 & 2.88 & 2.57 \\
$\mathrm{~K}_{2} \mathrm{O}$ & 0.36 & 0.39 & 0.40 & 1.18 & 0.62 & 0.67 & 0.78 & 0.63 & 1.09 & 1.02 \\
$\mathrm{~F}_{2} \mathrm{O}_{5}$ & 0.06 & 0.15 & 0.13 & 0.22 & 0.10 & 0.18 & 0.23 & 0.20 & 0.10 & 0.11 \\
\hline
\end{tabular}

OS 12 OS 13 OS 14 OS 15 YS 1 YS 2 YS 3 CC 1 CC2

\begin{tabular}{lccccccccc}
\hline $\mathrm{SiO}_{2}$ & 64.0 & 59.8 & 59.9 & 68.4 & 67.0 & 67.5 & 69.3 & 76.2 & 74.8 \\
$\mathrm{TiO}_{2}$ & 0.74 & 0.74 & 0.71 & 0.42 & 0.50 & 0.46 & 0.37 & 0.18 & 0.26 \\
$\mathrm{Al}_{2} \mathrm{O}_{3}$ & 16.0 & 17.3 & 17.2 & 17.8 & 17.6 & 17.1 & 17.7 & 14.3 & 14.2 \\
$\mathrm{Fe}_{2} \mathrm{O}_{3}$ & 7.30 & 8.70 & 8.20 & 2.78 & 4.70 & 4.27 & 3.01 & 1.53 & 2.10 \\
$\mathrm{MnO}$ & 0.17 & 0.14 & 0.14 & 0.08 & 0.10 & 0.11 & 0.09 & 0.02 & 0.07 \\
$\mathrm{MgO}$ & 2.60 & 3.34 & 3.53 & 1.11 & 1.99 & 1.99 & 1.42 & 0.52 & 0.80 \\
$\mathrm{CaO}$ & 5.40 & 5.72 & 6.35 & 4.78 & 4.58 & 3.80 & 3.17 & 1.91 & 1.93 \\
$\mathrm{Na}_{2} \mathrm{O}$ & 2.48 & 3.22 & 2.86 & 3.03 & 2.33 & 3.22 & 3.31 & 3.04 & 3.49 \\
$\mathrm{~K}_{2} \mathrm{O}$ & 1.13 & 0.93 & 0.89 & 1.54 & 1.18 & 1.42 & 1.51 & 2.28 & 2.28 \\
$\mathrm{p}_{2} \mathrm{O}_{5}$ & 0.23 & 0.18 & 0.20 & 0.08 & 0.08 & 0.17 & 0.15 & 0.04 & 0.08 \\
\hline
\end{tabular}


groundmass $\mathrm{SiO}_{2}$ contents also increase successively from the type 1 to the type 5 .

\section{Mineral chemistries}

Chemical compositions of minerals were determined by a JEOL X-ray micro-probeanalyzer Model IXA-5. The analytical methods are those described by Nakamura and Kushiro (1970a).

Olivine : Olivine (0.1-0.5 $\mathrm{mm}$ across) occurs as phenocrysts in the rocks of the type 1 . Its Fo content varies from 74 to 55 mole\% (Fig. 2). Some olivine phenocrysts are surrounded with thin hypesthene reaction rims whose thickness is less than $0.1 \mathrm{~mm}$ and others are surrounded with fine-grained pigeonite. Olivine is normally zoned from the core to the rim. $\mathrm{Fe}^{2+}-\mathrm{Mg}$ partition coefficients between cores of olivine and its surrounding groundmass are within the range of 0.26 to 0.35 , assuming that the $\mathrm{Fe}_{2} \mathrm{O}_{3} /$ $\mathrm{FeO}$ ratio of the groundmass is 0.1 , which is the lowest value of the rocks of the northeastern Japan (Kawano et al., 1961). The olivine cores are likely to be equilibrated with the liquids with respect to $\mathrm{Fe}^{2+}-\mathrm{Mg}$ partition (Roeder and Emslie, 1970). Intergrowth of olivine and large augite phenocrysts are rarely observed.

Hypersthene: Hypersthene occurs as euhedral or subhedral phenocrysts in all the rocks. Their chemical compositions are shown in Fig. 2. In the type 1 rocks, En contents of the phenocryst cores range from 73 to $67 \mathrm{~mole} \%$. In the rocks of other types, they are within the range of 60 to $68 \mathrm{~mole} \%$. In spite of wide variation of $\mathrm{SiO}_{2}$ contents of the groundmass, $\mathrm{Fe} / \mathrm{Fe}+\mathrm{Mg}$ ratios of hypersthene phenocrysts are not largely varied (Fig. 2). This is concordant with small range of the $\mathrm{FeO}^{*} / \mathrm{MgO}$ ratios of the groundmass (Fig. 9). Wollastonite (Wo) contents of cores of hypersthene phenocrysts are in the range of 2.8 to 4 mole\% in the rocks of the type 1 to 2 . In the type 4 rocks which contain hornblende phenocrysts, they are in the range of 2 to $3 \mathrm{~mole} \%$. They are less than 2 mole\% in the type 5 rocks. Sakuyama (1979, 1981) showed that the Wo contents of hypersth. ene phenocrysts coexisting with hornblende phenocrysts are generally less than 3 mole\% which is constant even in different volcanoes. The present result also supports his argument.

Most of hypersthene phenocrysts have wide homogeneous cores. They have normally zoned rims in most of the rocks of type 1, 2 and 3. In some rocks, however, reversely zoned rims are observed. The variation of $\mathrm{Fe} / \mathrm{Fe}+$ $\mathrm{Mg}$ ratio in such a reversely zoned rim is less than 0.03 . In the rocks of the types 4 and 5 , which have glassy groundmass, hypersthene phenocrysts are poorly zoned. Groundmass hypersthene which is more enriched in $\mathrm{Mg}$ than phenocrysts is found in some rocks of the type 4.

Augite: Augite occurs as phenocrysts and groundmass constituents. Its chemical compositions are shown in Fig. 2. Augite phenocrysts have wide homogeneous cores. $\mathrm{Fe} / \mathrm{Fe}+\mathrm{Mg}$ ratios of augite phenocrysts show a small variation from 0.75 to 0.65 . Two kinds of augite phenocryst are recognized in the type 1 rocks in terms of size and chemical composition. The larger one $(0.5-2 \mathrm{~mm})$ has $43-45$ mole\% of wollastonite content and 3-5 wt \% of $\mathrm{Al}_{2} \mathrm{O}_{3}$ content. The intergrowth of the larger augite and olivine phenocryst is often observed. The smaller one $(0.2-0.5 \mathrm{~mm})$ has lower wollastonite content (40-42 mole\%) and lower $\mathrm{Al}_{2} \mathrm{O}_{3}$ content (1.7-3.5 wt\%) than the larger one. The larger augite phenocryst might have crystallized a little earlier than the smaller one.

Wollastonite contents of augite phenocrysts increase from the type 2 and 3 rocks to the type 4 rocks ; $42-39$ mole\% for augite phenocrysts in the type 2 and 3 rocks, and $44-45$ mole\% for those in the type 4 rocks.

Pigeonite: Pigeonite occurs as microphenocrysts, groundmass constituents and reaction rims around hypersthene and olivine pheno. 

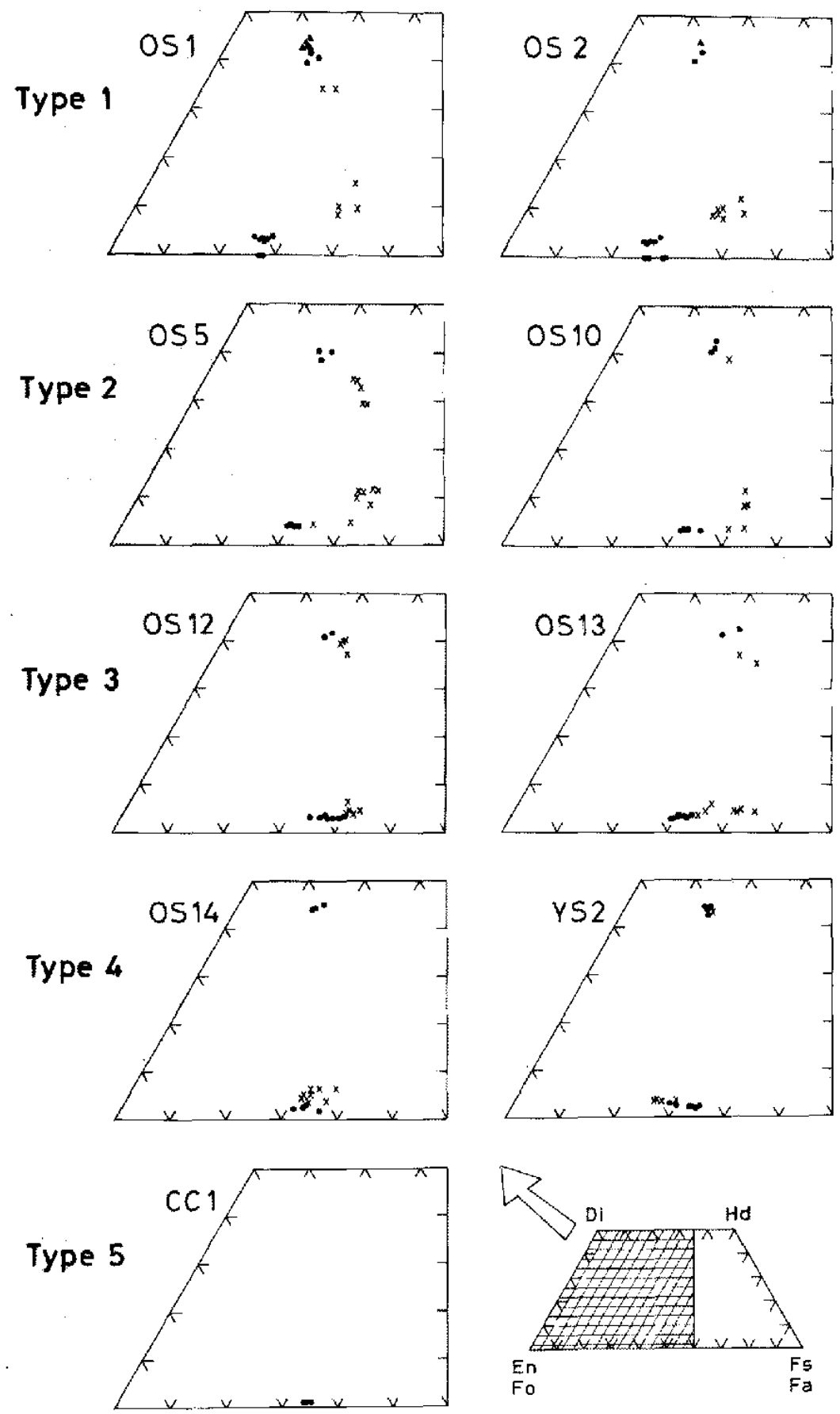

Fig. 2. Chemical compositions of pyroxenes and olivine in the rocks of the Akagi volcano. Solid circles, cores of phenocrysts; Crosses, groundmass pyroxenes; Solid triangles, large phenocrysts in the rocks of the type 1. 
crysts. Microphenocryst pigeonite $(<0.3 \mathrm{~mm})$ is found only in two samples of type 1 and type 2. Groundmass pigeonite occurs in the rocks of type 1 and 2 as short or slightly elongated prisms. Fine-grained pigeonites surround hypersthene and olivine phenocrysts in the type 1 rocks. In some of the type 2 rocks, intergrowth of pigeonite and hypersthene is observed at the rim of hypersthene phenocryst. Pigeonite does not occur in the rocks of types 3 , 4 and 5.

Plagioclase: Plagioclase abundantly occurs as euhedral phenocrysts and groundmass constituents. Plagioclase phenocrysts contain glass and dusty inclusions in cores. An content is nearly constant or fluctuates within 10 mole\% in a core of a phenocryst. In the rocks of type 1 , An contents of cores of plagioclase phenocrysts range from 96 to 85 mole\%. In the rocks of types 2 and 3 , they show a wide variation from 90 to 60 mole\% except for some rocks (OS9 and OS4) in which they range from 90 to $70 \mathrm{~mole} \%$. An contents vary from 90 to 60 mole\% in the type 4 rocks and from 90 to 50 mole\% in the rocks of type 5 . In spite of a wide variation in an individual rock, the average An contents of phenocryst cores are well correlated with $\mathrm{SiO}_{2}$ content of groundmass (Fig. 3); the average An content decreases from 90 to 70 mole\% with increasing $\mathrm{SiO}_{2}$ content of groundmass.

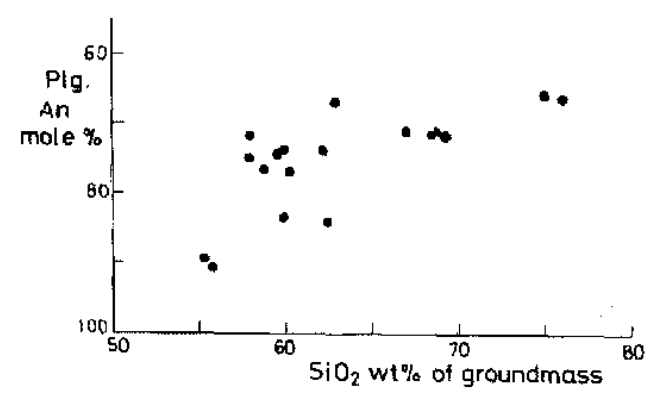

Fig. 3. Correlation between $\mathrm{Na} / \mathrm{Na}+\mathrm{Ca}$ mole ratios of plagioclase phenocrysts and $\mathrm{SiO}_{2}$ contents of groundmass.
Hornblende: Hornblende phenocryst occurs in the rocks of types 4 and 5 . Hornblende phenocrysts in the type 4 rocks are less than $0.3 \mathrm{~mm}$ across and small in quantity $(<0.4$ vol\%). They show brown to pale brown pleochroism with opacitized rims. In the type 5 rocks, hornblende phenocrysts, 0.2 to $0.5 \mathrm{~mm}$ across, are larger than those in the type 4 rocks. Their pleochroism is pale green to pale brownish green. They show no opacitization.

Oxide minerals: Magnetite occurs as phenocrysts and groundmass constituents. Magnetite phenocrysts are contained in all of the rock types. The $\mathrm{TiO}_{2}$ contents range from 5 to $15 \mathrm{wt} \%$. Magnetite inclusions in olivine phenocrysts (Fo70-73) are slightly enriched in $\mathrm{Al}_{2} \mathrm{O}_{3}$ content than the phenocrysts. Ulvöspinel mole\% in magnetite decreases con. tinuously from 35 in the type 1 rocks to 16 in the type 5 rocks.

Euhedral ilmenite phenocrysts occur in the hornblende bearing rocks. Composite grains of ilmenite and magnetite are occasionally observed. The $\mathrm{TiO}_{2}$ contents of ilmenite phenocrysts range from 33 to $40 \mathrm{wt} \%$. Hematite mole\% in ilmenite in the type 4 rocks is 35 in average and it is about 29 in the type 5 rocks.

\section{Crystallization Sequence and liquid line of descent}

The crystallization sequence in the magma reservoir of the Akagi volcano can be obtained from the relationship between phenocryst assemblages and groundmass $\mathrm{SiO}_{2}$ contents. The sequence is described in terms of increasing $\mathrm{SiO}_{2}$ content of the liquid (groundmass) as shown below. In the liquid whose $\mathrm{SiO}_{2}$ content is less than $56 \mathrm{wt} \%$, olivine, plagioclase, augite, hypersthene and magnetite coexist. With increasing $\mathrm{SiO}_{2}$ content of the liquid, olivine disappears and the assemblage of crystallizing minerals becomes augite, hypersthene, magnet- 
ite and plagioclase. From the liquid whose $\mathrm{SiO}_{2}$ content is $60-65 \mathrm{wt} \%$, hornblende and ilmenite begin to crystallize. Augite ceases to crystallize in the liquid with $\mathrm{SiO}_{2}$ content more than $70-75$ wt\%.

The crystallization sequence of the Akagi volcano is compared with that of the Hotaka volcano in Fig. 4. The distinct differences are early crystallization of hornblende and ilmenite and disappearance of augite in the Akagi volcano.

These crystallization sequences must have been caused by the contemporaneous temperature decrease. A liquid line of descent of the magma should be a function of magmatic temperature. The magmatic temperatures of the magmas of the Akagi and Hotaka volcanoes were estimated by two-pyroxene geothermometer (Wells, 1977) using averaged chemical compositions of cores of phenocrysts. Calculations were performed assuming that only $\mathrm{Fe}$, $\mathrm{Mg}$ and Ca occupy the octahedral sites of pyroxenes and that the tetrahedral sites are filled by $\mathrm{Si}$. Incorporation of $\mathrm{Al}$ and $\mathrm{Ti}$ in pyroxenes does not affect the following discus. sion because of the low $\mathrm{Al}$ and $\mathrm{Ti}$ contents of pyroxenes except some augite phenocrysts with high $\mathrm{Al}_{2} \mathrm{O}_{3}$ content in the type 1 rocks of the

HOTAKA
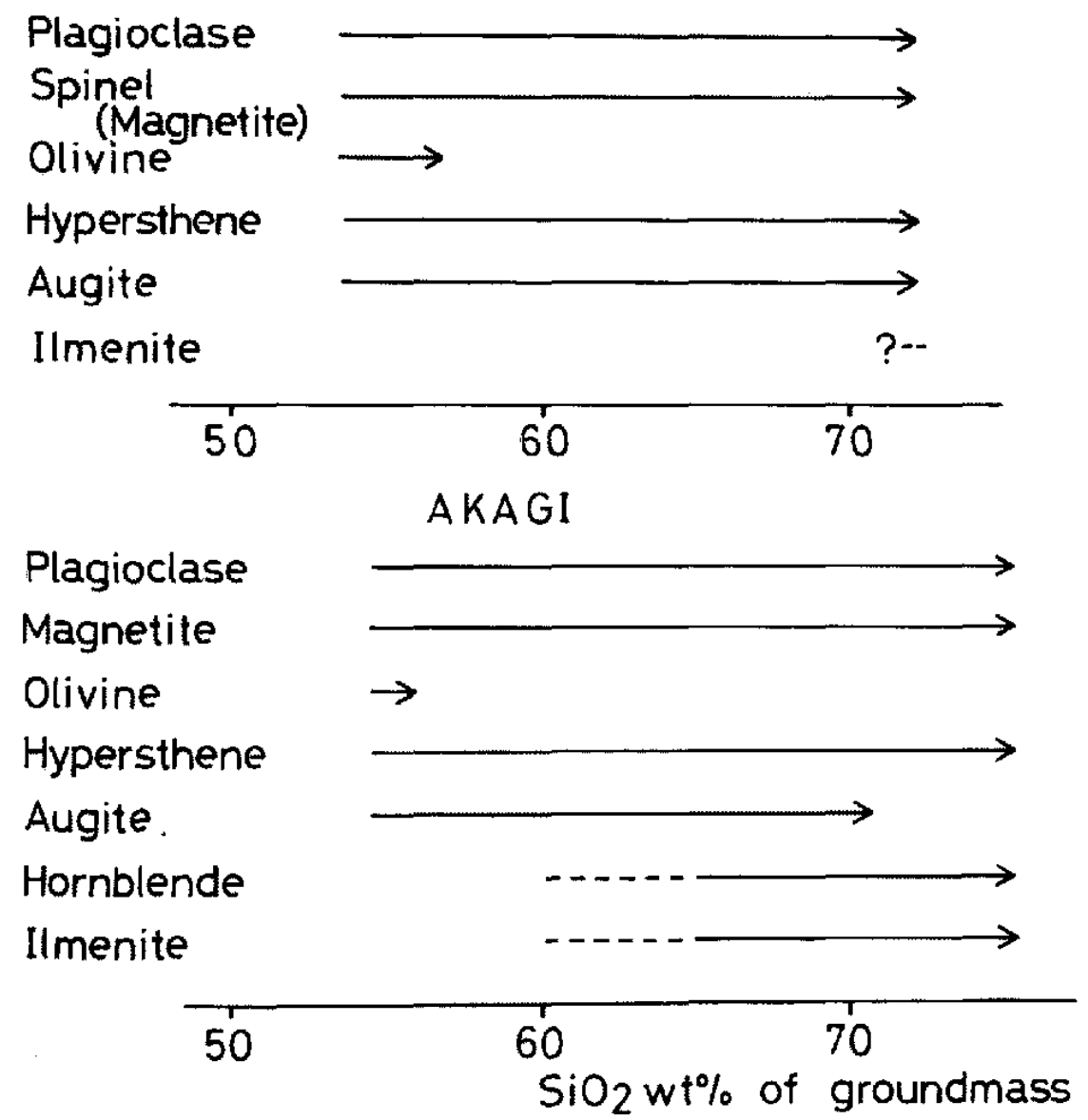

Fig. 4. Comparison of crystallization sequences with increasing $\mathrm{SiO}_{2}$ content of groundmass in the Akagi and Hotaka volcanoes. 
Akagi volcano. The compositions of the augite phenocrysts with high $\mathrm{Al}_{2} \mathrm{O}_{3}$ content in the type 1 rocks were not used in the calculation.

The relationship between the temperature and $\mathrm{SiO}_{2}$ content of the groundmass is shown in Fig. 5. The figure shows decreasing magmatic temperature with increasing the $\mathrm{SiO}_{2}$ content of groundmass. The calculated temperatures of the rocks with hornblende phenocrysts are lower than those of the rocks without hornblende phenocrysts in the Akagi volcano. The result is consistent with the experimental studies under the hydrous conditions (Piwinskii, 1973; Eggler, 1972; Eggler and Burnham, 1973).

The trend for the Akagi volcano has a steeper slope than that for the Hotaka volcano. In the Akagi volcano, the temperature variation is about $130^{\circ} \mathrm{C}$ while the $\mathrm{SiO}_{2}$ content of groundmass changes from 54 to $70 \mathrm{wt} \%$. On the other hand, the temperature variation is only about $60^{\circ} \mathrm{C}$ while the $\mathrm{SiO}_{2}$ content of groundmass changes from 54 to $70 \mathrm{wt} \%$ in the Hotaka volcano. The rate of increase of liquid $\mathrm{SiO}_{z}$ content for a given temperature decrease

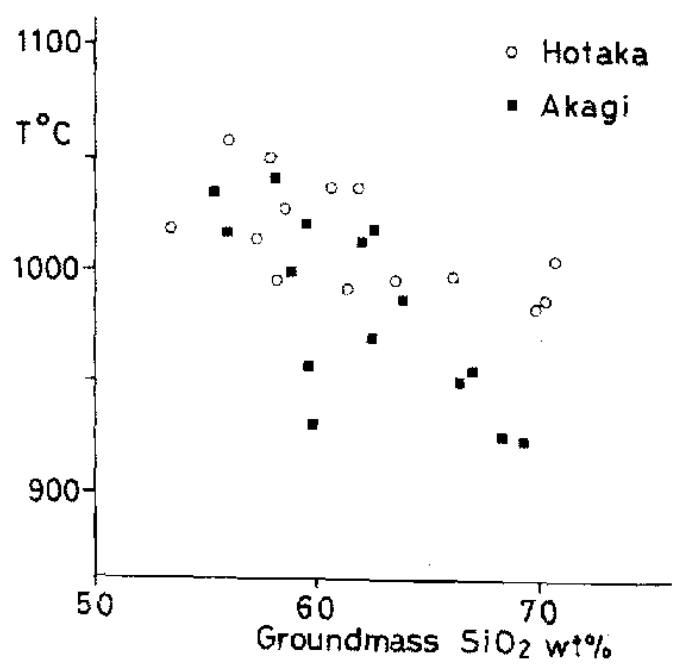

Fig. 5. Change of magmatic temperature with increasing $\mathrm{SiO}_{2}$ content of groundmass. is small in the magma of the Akagi volcano than in the magma of the Hotaka volcano, This strongly suggests that the degree of crystallization for a given temperature decrease in the Akagi volcano is smaller than that in the Hotaka volcano.

The amounts of crystallized minerals were estimated by linear least-squares mixing calcu. lations. The details of calculation procedure is given in the later section. The estimated amounts are 35 and $37 \mathrm{wt} \%$ for the Hotaka and Akagi magmas respectively while the $\mathrm{SiO}_{2}$ content of liquids changes from 57 to $65 \mathrm{wt} \%$. This indicates that the increase of the $\mathrm{SiO}_{2}$ content roughly corresponds to that of the percentage solidified. Therefore, the different rate of increasing $\mathrm{SiO}_{2}$ content for a given temperature decrease shows the different rate of increase of percentage solidified.

The early crystallization of homblende in the Akagi volcano shown in Fig. 4 reflects a large temperature descent with increasing degree of crystallization.

\section{Effect of $\mathrm{H}_{2} \mathrm{O}$ on the liquid line of descent}

It will be discussed in this section how the difference in $\mathrm{H}_{2} \mathrm{O}$ content of the initial liquids affects the relationship between temperature and solid fraction in their cooling history.

As long as a magma remains undersaturated with $\mathrm{H}_{2} \mathrm{O}$ and only anhydrous minerals crys. tallize from it, $\mathrm{H}_{2} \mathrm{O}$ content in the magma increases. The rate of increasing $\mathrm{H}_{2} \mathrm{O}$ content in liquid during solidification depends on the intial $\mathrm{H}_{2} \mathrm{O}$ content ; $\mathrm{H}_{2} \mathrm{O}$ contents in the liquids after $50 \mathrm{wt} \%$ solidification are 0.6 and $4 \mathrm{wt} \%$ when initial $\mathrm{H}_{2} \mathrm{O}$ contents are 0.3 and $2 \mathrm{wt} \%$ respectively. Initial difference in absolute content of $\mathrm{H}_{2} \mathrm{O}$ is exaggerated by crystallization of anhydrous phases, and this difference actually has a great effect on the phase relations and resultunt cooling history.

This is examplified by the simple Albite- 
$\mathrm{H}_{2} \mathrm{O}$ system (Fig. 6A). The relationship between temperature and solid fraction is shown for liquids with 0.5 and $2 \mathrm{wt} \% \mathrm{H}_{2} \mathrm{O}$ (A and $B$ respectively) in Fig. $6 \mathrm{~B} . \quad 45 \mathrm{wt} \%$ of liquid $\mathrm{A}$ is solidified by a $30^{\circ} \mathrm{C}$ decrease and only 20 wt $\%$ of liquid $B$ is solidified by the same temperature decrease. This difference is simply caused by the steep decrease of liquidus temperature against increasing $\mathrm{H}_{2} \mathrm{O}$ in the liquid (Fig. 6A).

Drastic decrease of liquidus temperatures of plagioclase and pyroxenes by addition of $\mathrm{H}_{2} \mathrm{O}$ has been observed in hydrous experiments on natural andesitic systems (Eggler, 1972; Eggler and Burnham, 1973; Sekine, et al.,

A

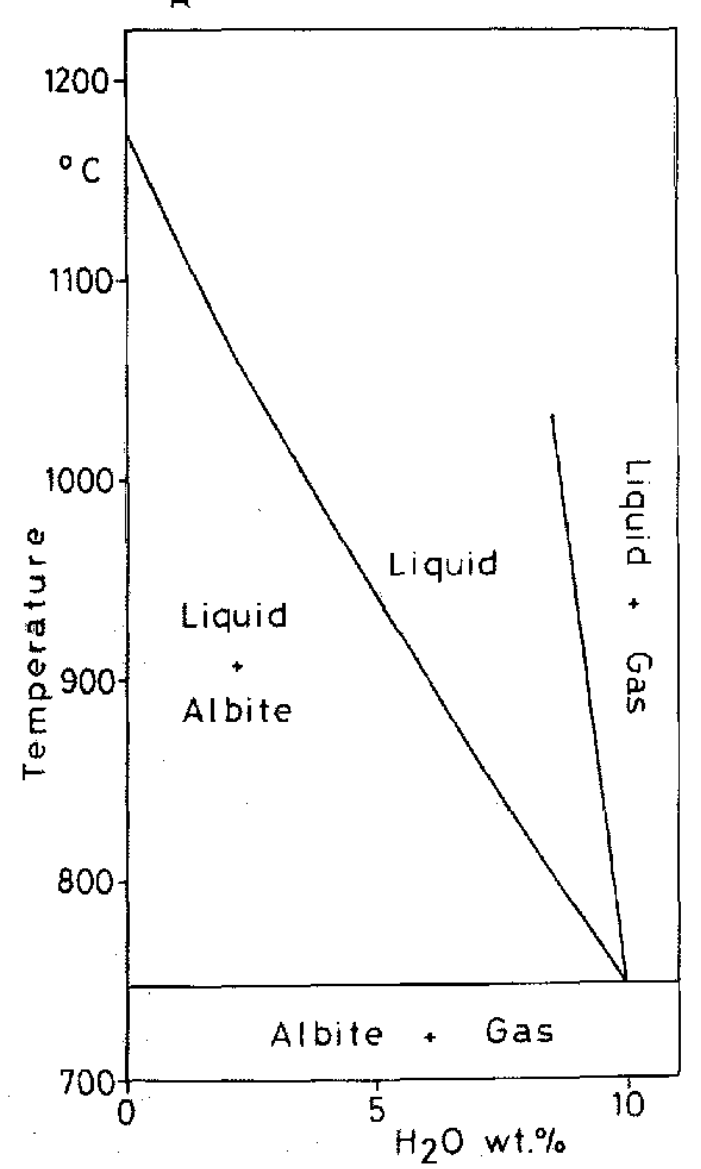

1979). Temperature descent of plagioclase liquidus from its anhydrous one by adding $\mathrm{H}_{2} \mathrm{O}$ is plotted against $\mathrm{H}_{2} \mathrm{O}$ content in the liquids (Fig. 7A). The values of $\Delta T_{p}$ ? represented by open squares were obtained from the temperature difference between the dry plagioclase liquidus at $1 \mathrm{~atm}$ and the crossing point of plagioclase and pyroxene liquidus under $\mathrm{H}_{2} \mathrm{O}$-saturated condition, based on the data of Sekine et al. (1979). In this figure, the effect of pressure on the liquidus is neglected because the pressure of the crossing point under $\mathrm{H}_{2} \mathrm{O}$-saturated condition are less than $1 \mathrm{~kb}$. The values of $\Delta T_{p}$ represented by other symboles were obtained from the temperature difference between the

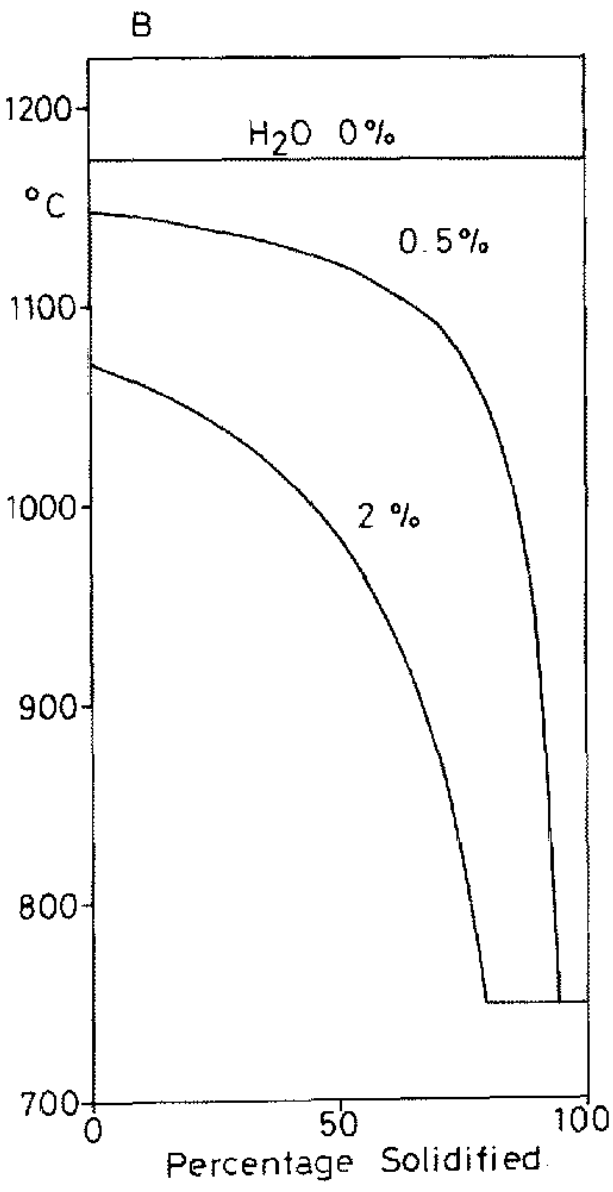

Fig. 6. A, Phase diagram of Albite- $\mathrm{H}_{2} \mathrm{O}$ system at $5 \mathrm{~kb}$ (Burnham and Jahns, 1962). B, Change of solid fraction with decreasing temperature. 

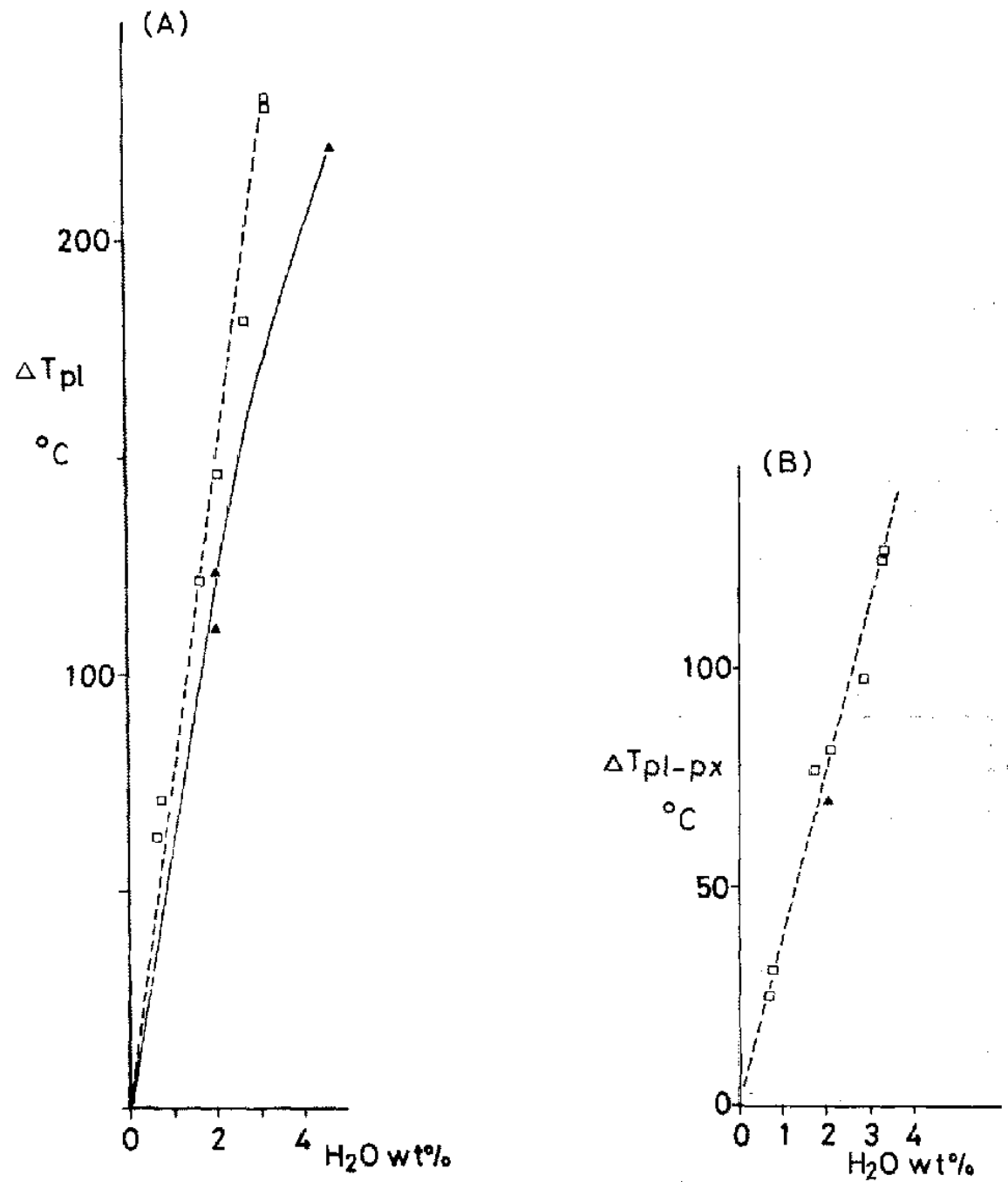

Fig. 7. Descent of liquidus temperature with the addition of $\mathrm{H}_{2} \mathrm{O}, \mathrm{A}$, Plagioclase liquidus tempera. ture. Open squares represent the data of Sekine et al. (1979). The values of $\Delta T_{p 1}$ was obtained from temperature difference between dry plagioclase liquidus and the crossing point under $\mathrm{H}_{2} \mathrm{O}$-saturated condition. Solid triangles represent the data of Eggler (1972) and Eggler and Burnham (1973) at $5 \mathrm{~kb}$. B, Cotectic temperature of plagioclase and pyroxene. The data represented by open squares were obtained from the temperature difference between dry cotectics and the crossing point based on the data of Sekine at al. (1979). The data represented by solid triangles were obtained from Eggler (1972).

dry and $\mathrm{H}_{2} \mathrm{O}$-undersaturated liquidus of plagioclase. The data for Paricutin andesite at $5 \mathrm{~kb}$ (Eggler, 1972), Mt. Hood andesite at $5 \mathrm{~kb}$ (Egg. ler and Burnham, 1973) and Hata basalt at $8 \mathrm{~kb}$ (Yamaguchi, unpublished data) are plotted in the figure. The chemical composition of Hata basalt was shown by Kuno (1950).
The rates of decreasing plagiolcase liquid are very similar with each other and also simi lar to that in the Albite $\mathrm{H}_{2} \mathrm{O}$ system.

Decrease of the cotectic temperaturs between plagioclase and pyroxene from the anhydrous one is plotted against $\mathrm{H}_{2} \mathrm{O}$ content in the liquid (Fig. 7B). The data represented by 
open squares were obtained from the temperature difference between the dry cotectics at 1 atm and the crossing point under $\mathrm{H}_{2} \mathrm{O}$-saturated condition based on the data of Sekine $e t$ al. (1979). The data represented by solid symbols were obtained from the temperature difference at a given pressure between the dry cotectics and the crossing point under $\mathrm{H}_{2} \mathrm{O}$-undersaturated condition, using the data of Eggler (1972) and Yamaguchi (unpublished data). Fig. 7B shows that the depression of the temperature of plagioclase-pyroxene cotectics with the addition of $\mathrm{H}_{2} \mathrm{O}$ is remarkable.

Since data shown in Figs. 7A and B contain various kinds of bulk compositions, this relationship may also hold for crystallization of magmas in the Hotaka and Akagi volcanoes. As shown previously, actual magmatic liquids of the Hotaka and Akagi volcanoes are on the cotectic line of plagioclase and pyroxene, so that the decrease of the cotectic temperature in Fig. 7B is applicable to their cooling history. This figure suggests that even the difference of 1 or $2 \%$ in $\mathrm{H}_{2} \mathrm{O}$ content of the initial magmas makes a large difference of liquidus tempera. ture of fractionated magmas, and the rate of increase in solid fraction in the magma with a larger amount of initial $\mathrm{H}_{2} \mathrm{O}$ is smaller than that in the magma with a smaller amount of $\mathrm{H}_{2} \mathrm{O}$.

It is suggested from the above relations that the difference of the slope in the $\mathrm{T}-\mathrm{SiO}_{2}$ diagram (Fig. 5) is generated by the difference in $\mathrm{H}_{2} \mathrm{O}$ contents of the initial basaltic magmas and that the $\mathrm{H}_{2} \mathrm{O}$ content of the magma of the Akagi volcano is higher than that of the Hotaka volcano.

The difference in $\mathrm{H}_{2} \mathrm{O}$ contents should affect the chemical compositions of the magmas. Groundmass $\mathrm{Al}_{2} \mathrm{O}_{3}$ contents are plotted against groundmass $\mathrm{SiO}_{2}$ contents in Fig. 8 . In this figure, those of the Tongan islands (Ewart et al., 1973) are plotted as a reference of typical island arc tholeiites. $\quad \mathrm{Al}_{2} \mathrm{O}_{3}$ content of the liquid lines of descent increases in the order of the Tongan islands, Hotaka and Akagi.

The primary phase field of diopside expands relatively to that of anorthite under hydrous conditions in the diopside-anorthite system (Yoder, 1965). Some experimental

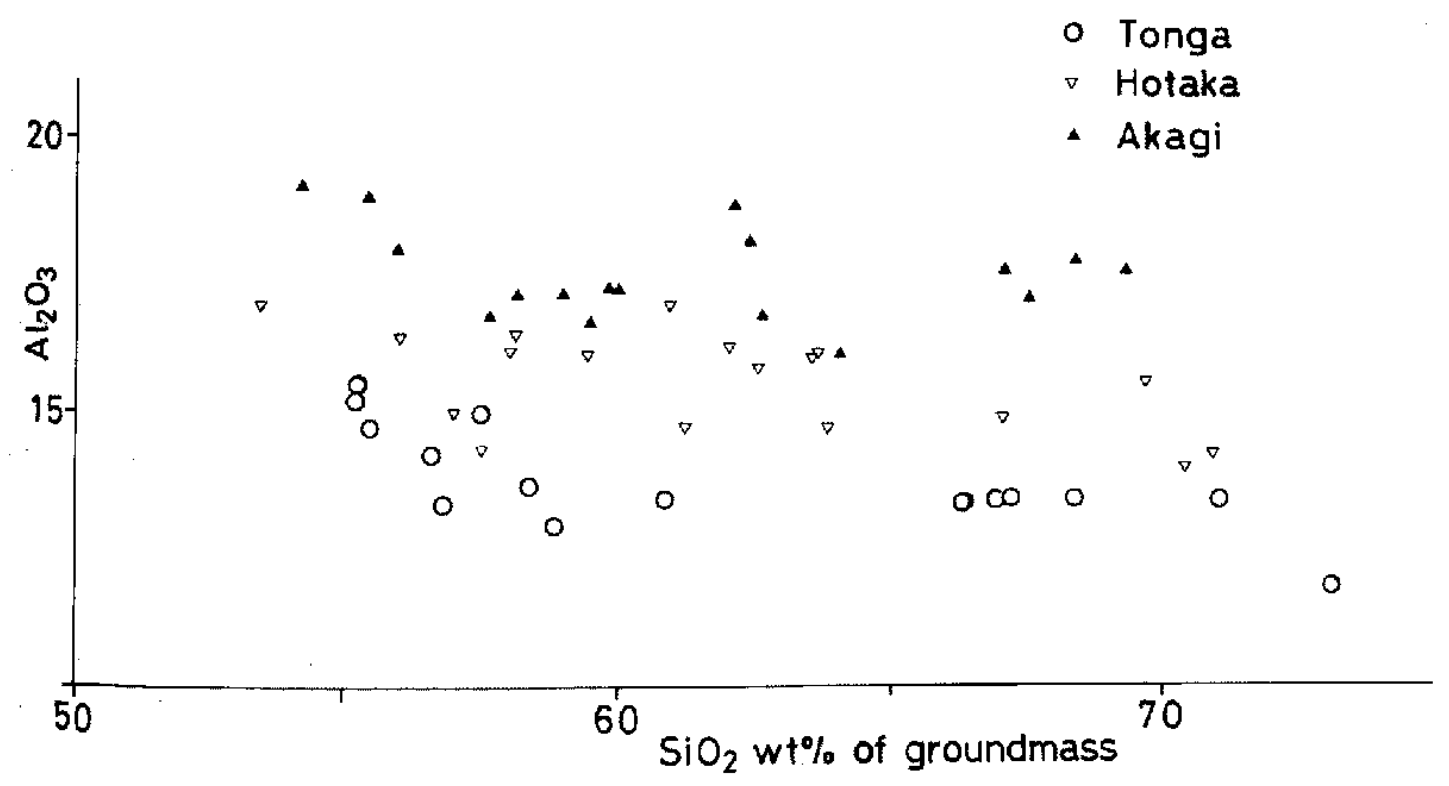

Fig. 8. Variation of $\mathrm{Al}_{2} \mathrm{O}_{3}$ contents against $\mathrm{SiO}_{2}$ contents. 
studies on natural rocks (Yoder, 1962 ; Eggler, 1972; Eggler and Burnham, 1973) show that the depression of plagioclase liquidus with the addition of $\mathrm{H}_{2} \mathrm{O}$ is more drastic than that of pyroxene liquidus. This indicates that the stability field of pyroxene expands against that of plagioclase, and consequently the composition of the cotectic liquid shifts toward plagioclase component. Thus, it is inferred that $\mathrm{Al}_{2} \mathrm{O}_{3}$ content of the cotectic liquid increases with the addition of $\mathrm{H}_{2} \mathrm{O}$. The different $\mathrm{Al}_{2} \mathrm{O}_{3}$ contents among different volcanoes (Fig. 8) might mainly reflect the different degrees of expansion of the diopside field with the different $\mathrm{H}_{2} \mathrm{O}$ contents. It is also suggested that the $\mathrm{H}_{2} \mathrm{O}$ content of the magma of the Akagi volcano is higher than that of the Hotaka volcano. The magma of the Tongan islands might be more depleted in $\mathrm{H}_{2} \mathrm{O}$ content than those of the Akagi and Hotaka volcanoes.

\section{Role of plagioclase fractionation on $\mathrm{FeO}^{*} /$ MgO ratio of the magmas}

Fig. 9A shows the ralationship between $\mathrm{FeO}^{*} / \mathrm{MgO}$ ratio and $\mathrm{SiO}_{2}$ content of groundmass in the Akagi and Hotaka volcanoes together with that of the Tongan islands (Ewart, 1973). In this section, the difference in change of $\mathrm{FeO}^{*} / \mathrm{MgO}$ ratio during fractional crystallization among different volcanoes is examined from the view point of proportions of fractionated minerals.

The amounts of plagioclase, augite, hypersthene and magnetite fractionated during crystallization of magmas were obtained by a linear least-squares mixing calculation. In the calculation, the chemical composition of a mafic rock was linearly connected with the chemical compositions of augite, hypersthene, magnetite, plagioclase and a felsic rock. The average chemical compositions of phenocryst minerals in the mafic rock and those in the felsic rock were used in the mixing calculation.
The mixing calculations on the Akagi magma were made using the compositions of groundmass obtained by least-squares fitting in the $\mathrm{SiO}_{2}$ variation diagrams of groundmass whose total phenocrysts contents are less than 35 volume\%. Effects of homblende and i1menite were neglected in the mixing calculation because they are in a small quantity compared with other mafic phenocrysts, and the compositions of the type 4 rocks containing hornblende and ilmenite phenocrysts are on the same linear trend as those of the rocks of types 2 and 3 in the $\mathrm{SiO}_{2}$ variation diagram. The type 5 rocks were omitted in the calculation of linear regres. sion because of absence of augite phenocrysts and abundance of hornblende phenocrysts.

The mixing calculations on the Hotaka magma were made using the compositions of groundmass and those obtained by leastsquares fitting in the $\mathrm{SiO}_{2}$ variation diagrams (Yamaguchi, 1984). The calculations on the magma of the Tongan islands were also made using the compositions of groundmass and those obtained by least-squares fitting in the $\mathrm{SiO}_{2}$ variation diagrams.

The weight ratios of the fractionated min. erals obtained by these calculations are plotted in the triangular diagram of pyroxenes plagioclase-magnetite (Fig. 10). There is a systematic difference in the ratios of plagioclase to the mafic minerals among the volcanoes. The plagioclase ratios range from 35 to $47 \%$ in the Tongan island, from 46 to $49 \%$ in the Hotaka volcano and $55 \%$ in the Akagi volcano. The ratios of magnetite range from 7 to $23 \%$ in the Tongan islands, from 9 to $12 \%$ in the Hotaka volcano and $12 \%$ in the Akagi volcano.

Fractionation of calcic plagioclase increases $\mathrm{SiO}_{2}$ content of a magma without changing $\mathrm{FeO}^{*} / \mathrm{MgO}$ ratio. It is confirmed by the simulative calculation that the observed variation of the plagioclase ratio (20\%) among the three different volcanoes can be sufficiently 


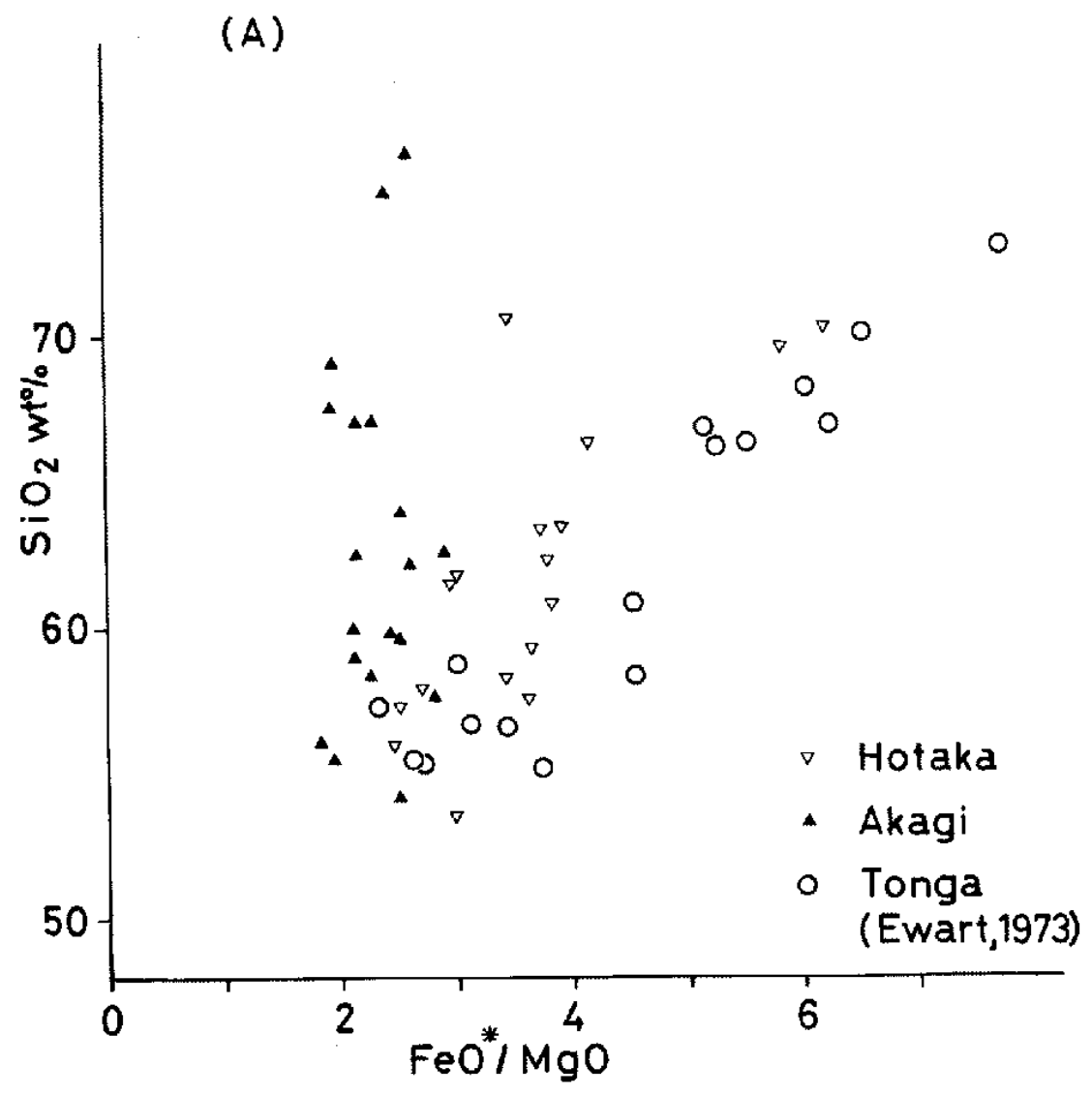

Fig. 9. A, Change of $\mathrm{SiO}_{2}$ content with increasing $\mathrm{FeO}^{*} / \mathrm{MgO}$ ratio in the Akagi volcano, the Hotaka volcano and the Tongan islands (Ewart et al., 1973). B, Calculation to simulate the change of $\mathrm{FeO}^{*} / \mathrm{MgO}$ ratio according to increasing $\mathrm{SiO}_{2}$ content when the minerals of given chemical compositions are fractionated from the magma of a given composition. A ratio of magnetite is fixed on 0.1 and a ratio of augite to hypersthene on $1: 1$. The line 1 shows the change of the liquid composition in fractional crystallization when plagioclase: pyroxene : magnetite is $6: 3: 1$. The broken line indicates the liquid derived from the liquid $\mathrm{A}$ by $25 \%$ fractionation.

effective on changing the relationship between $\mathrm{FeO} / \mathrm{MgO}$ and $\mathrm{SiO}_{2}$ content (Fig. $9 \mathrm{~B}$ ). In the simulative calculation the chemical compositions of augite (En35Fs15), hypersthene (En70Fs30) and plagioclase (An90Ab20) are subtracted from the magma composition $\mathrm{CSiO}_{2}$
57, FeO 9.3, MgO $3.8 \mathrm{wt} \%$ ). The proportion of magnetite in the subtracted minerals is fixed as 0.1 and the ratio of augite to hypersthene as $1: 1$. The result of the calculation suggests that the difference in the ratios of plagioclase is effective in generating the difference in the 


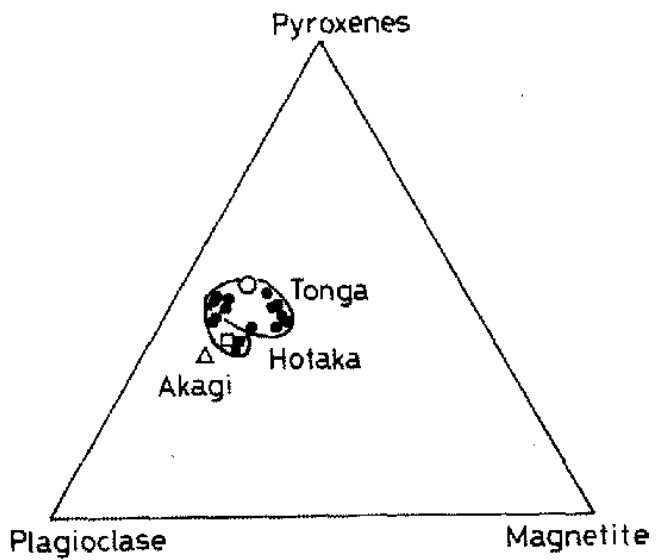

Fig. 10. Proportions of fractionated minerals. Solid circles, the proportions calculated for the groundmass in the Tongan islands (based on the data by of Ewart et al., 1973); Solid squares, aphyric rocks in the Hotaka voicano. Open symbols represent results of calculation using compositions obtained by least-squares fitting in $\mathrm{SiO}_{2}$ diagrams; Open circle, groundmass in the Tongan islands; Open square, aphyric rocks in the Hotaka volcano; Open triangle, groundmass in the Akagi volcano.

variation of $\mathrm{FeO} / \mathrm{MgO}$ ratio against $\mathrm{SiO}_{2}$.

The high ratio of plagioclase in the Akagi volcano refiects the highly aluminous liquid line of descent of the magma (Fig. 8). Plagioclase fractionation becomes more important in the fractional crystallization of the magma with higher alumina content. In the previous section, it was inferred that the magma of the Akagi volcano is richer in $\mathrm{H}_{2} \mathrm{O}$ content than those of the Hotaka volcano and the Tongan islands. The $\mathrm{Al}_{2} \mathrm{O}_{3}$ content (plagioclase component) of the cotectic composition in the system plagioclase-pyroxenes increases with the addition of $\mathrm{H}_{2} \mathrm{O}$. The higher ratio of plagioclase in the Akagi volcano might therefore be attributed to the higher $\mathrm{H}_{2} \mathrm{O}$ content of the magma.

Magnetite begins to crystallize from the liquid with the lower $\mathrm{FeO}^{*} / \mathrm{MgO}$ ratio in the Akagi than in the Tongan islands (Ewart, 1973), though it is uncertain whether magnetite crystallizes earlier in the Akagi volcano than in the Hotaka volcano. The temperature and oxgen fugacity were calculated for the coexisting magnetite and ilmenite phenocrysts by the method of Spencer and Lindsley (1981). The coexisting pair of $\mathrm{CC} 2$ gives $10^{-10.6} \mathrm{f}_{0_{2}}$ and $875^{\circ} \mathrm{C}$. That of OS14 gives $10^{-8,9} \hat{O}_{O_{2}}$ and $1010^{\circ} \mathrm{C}$. On the diagram of temperature and oxgen fugacity (Gill, 1981: Hildreth, 1981) the values for the Akagi volcano are plotted in the relatively oxidized region. Earlier crystallization of magnetite in the Akagi volcano than in the Tongan islands might be related to the relatively high $f_{0_{z}}$ of the magma.

Osborn (1959) explained that the difference in the variation of $\left(\mathrm{FeO}+\mathrm{Fe}_{2} \mathrm{O}_{3}\right) /(\mathrm{FeO}+$ $\mathrm{Fe}_{2} \mathrm{O}_{3}+\mathrm{MgO}$ ) vs. $\mathrm{SiO}_{2}$ is due to the difference in $\mathrm{f}_{\mathrm{O}_{2}}$ and later to the difference in the level of $\mathrm{f}_{\mathrm{O}_{2}}$ buffering (Osborn, 1977; 1979). According to him, crystallization of magnetite plays an important role in determining the chemistry of the liquid line of descent.

In the case of the Akagi volcano a small increase of $\mathrm{FeO}^{*} / \mathrm{MgO}$ ratio with increasing $\mathrm{SiO}_{2}$ may not be attributed simply to early crystallization of magnetite; it may also be related to the high proportion of plagioclase in the fractionated minerals.

\section{Relationship between pigeonitic and hyper- sthenic rock series}

Fig. 11 shows the relationship between $\mathrm{FeO}^{*} /\left(\mathrm{FeO}^{*}+\mathrm{MgO}\right)$ ratios of groundmass and magmatic temperatures. The change of $\mathrm{FeO}^{*} /\left(\mathrm{FeO}^{*}+\mathrm{MgO}\right)$ ratio with the change of magmatic temperature in the Akagi volcano is smaller than that in the Hotaka volcano.

As shown previously, in the Akagi volcano groundmass pyroxenes of the type 1 and 2 rocks are pigeonite \pm augite \pm hypersthene. That of the type 3 rocks is hypersthene+augite. Groundmass hypersthene occurs with or with- 


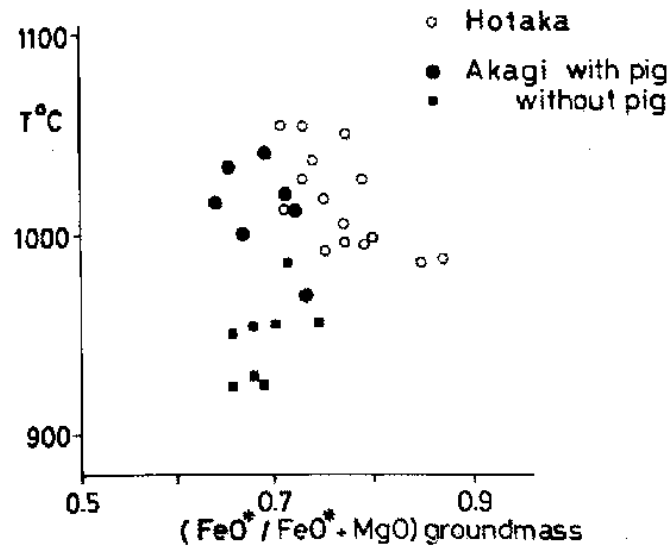

Fig. 11. Relationship between $\mathrm{FeO}^{*} / \mathrm{FeO}^{*}+\mathrm{MgO}$ ratio of groundmass and magmatic temperature.

out augite in the type 4 rocks. In the Hotaka volcano the change of the groundmass pyroxene assemblage is pigeonite + augite $\rightarrow$ pigeonite $\rightarrow$ pigeonite +hypersthene $\rightarrow$ hypersthene. Even when only hypersthene occurs in the groundmass, pigeonite occurs as reaction rims around augite phenocrysts.

The difference in the change of groundmass pyroxene assemblage is well explained by the change of pyroxene component schematically shown in Fig. 12. Stability of pigeonite depends on $\mathrm{Fe} / \mathrm{Mg}$ ratio and temperature of the liquid (Nakamura and Kushiro, 1970; Ishii , 1975). The pyroxene component of the liquid of the Hotaka magma is above the pigeonite eutectoid reaction line (Ishii, 1975) throughout the fractional crystallization, whereras that of the Akagi magma is changed across it. The systematic change of the assemblage of groundmass pyroxenes in the Akagi volcano (Table 2) reflects the small variation of $\mathrm{FeO}^{*}$ / $\mathrm{MgO}$ ratio of the successive liquid for the large decrease of the temperature shown in Fig. 11, whereras that in the Hotaka volcano reflects the large change of the $\mathrm{FeO}^{*} / \mathrm{MgO}$ ratio for the small decrease of the temperature.

According to Kuno (1950), the hypersthenic rock series (H-series) is characterized by the

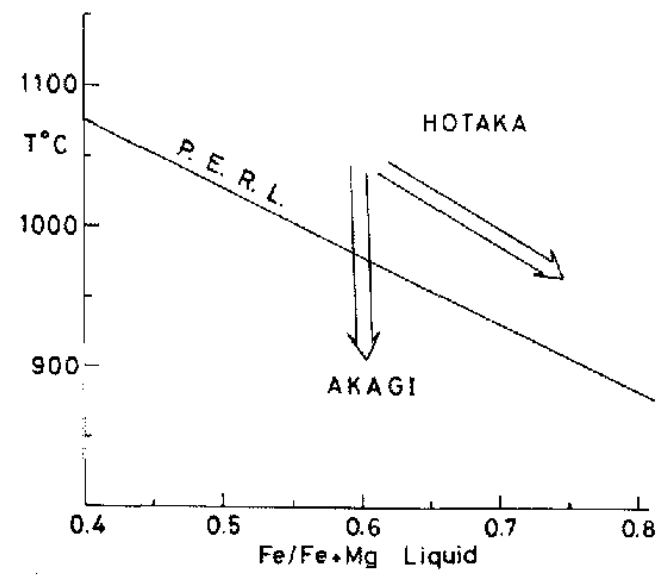

Fig. 12. Schematic change of pyroxene component. Solid line (P.E.R.L.) is the "pigeonite eutectoid reaction line" after Ishii (1975).

presence of groundmass orthorhombic pyrox. ene, with or without groundmass monoclinic pyroxene, whereas the pigeonitic rock series (P-series) is characterized by the presence of monoclinic pyroxene without groundmass orthorhombic pyroxene. He attributed generation of the $\mathrm{H}$-series magma from $\mathrm{P}$-series one to contamination of crustal materials (Kuno, 1950) and later to the concentration of $\mathrm{H}_{2} \mathrm{O}$ in the upper part of the magma reservoir (Kuno, 1959). This classification has been accepted by most of Japanese petrologists and $\mathrm{H}$-series has been understood as a synonym of calc-alkaline rock series (Kuno, 1966).

In the Hotaka and Akagi volcanoes, the rocks with or without groundmass hypersthene belong to a series formed by fractional crystal. lization; P-series magma differentiates to produce H-series magma. Sakuyama (1981) shows that the magmas of the Myoko and Kurohime volcanoes differentiate from olivineaugite basalt ( $\mathrm{P}$-series) to hornblende-hypersthene dacite ( $\mathrm{H}$-series) and that the magmas formed by internal mixing between the magmas of the same continuous differentiation trend also belong to $\mathrm{H}$-series. These observations suggest that fractional crystallization of $\mathrm{P}$ - 
series magmas is one of major processes generating $\mathrm{H}$-series magnas.

\section{Conclusions}

Arc magmas which have different initial $\mathrm{H}_{2} \mathrm{O}$ contents show different fractional crystal. lization paths: $\mathrm{H}_{2} \mathrm{O}$-enriched magma is char acterized by a rapid decrease of magmatic temperature with small degree of fractional crystallization. The $\mathrm{H}_{2} \mathrm{O}$-enriched magma is enriched in $\mathrm{Al}_{2} \mathrm{O}_{3}$ as a result of the expansion of pyroxene stability field against that of plagioclase.

Different degrees of iron-enrichment on $\mathrm{FeO}^{*} / \mathrm{MgO}^{-\mathrm{SiO}_{2}}$ diagram can be attributed partly to different proportions of plagioclase in the fractionated minerals; the higher propor tion of plagioclase separation results in $\mathrm{SiO}_{2}-$ enrichment trends with nearly constant $\mathrm{FeO}^{*} /$ $\mathrm{MgO}$ ratios. The high proportion of plagioclase reflects the highly aluminous liquid line of descent which would result from the high $\mathrm{H}_{2} \mathrm{O}$ content.

The continuous change from the pigeonitic rock series to the hypersthenic rock series through fractional crystallization is observed in several Japanese arc volcanoes. This suggests that fractional crystallization of $\mathrm{P}$-series magmas is one of major processes generating $\mathrm{H}$ series magmas.

Acknowledgements: The auther is heartly grateful to Professor I. Kushiro for critically reading and improving the manuscript. $\mathrm{He}$ is also indebted to Professors S. Aramaki and T. Fujii and the late Dr. M. Sakuyama for their useful discussions and encouragements.

\section{References}

Bryan, W.B., Finger, I.W. and Chayes, F. (1969), Estimating proportions in petrographic mix. ing equations by least square approximation. Science, 163, 926-927.
Burnham, C.W and Davis, N.F. (1974), The role of $\mathrm{H}_{2} \mathrm{O}$ in silicate melts: II. Thermodynamic and phase relations in the system $\mathrm{NaAlSi}_{2} \mathrm{O}_{\mathrm{g}}-$ $\mathrm{H}_{2} \mathrm{O}$ to 10 kilobars, 700 to $1100^{\circ} \mathrm{C}$. Amer. $J$. Sci., 274, 902-940.

Burnham, C.W. and Jahns, R.H. (1962), A method for determining the solubility of water in sili. cate melts. Amer. J. Sci., 260, 721-745.

Eggler, D.H. (1972), Water-saturated and undersaturated melting relations in a Paricutin andesite and estimate of water content in the natural magma. Contrib. Mineral. Petrol., 34, 261-271.

Eggler, D.H. and Burnham, C.W. (1973), Crystal15. zation and fractionation trends in the system andesite $-\mathrm{H}_{2} \mathrm{O}-\mathrm{CO}_{2}-\mathrm{O}_{2}$ at pressures to $10 \mathrm{~kb}$ Bull. Geol. Soc. Amer, 84, 2517-2532.

Ewart, A., Bryan, W. and Gill, J. (1973), Mineralogy and geochemistry of the younger volcanic islands of Tonga, S.W. Pacific. J. Petrol, 14, 429-465:

Gill, J.B. (1981), Orogenic andesites and plate tectonics. Springer-Verlag, Berlin, $390 \mathrm{pp}$.

Hildreth, W. (1.981), Gradients in silicic magma chambers: implications for lithospheric magmatism. J. Geophys. Res., 86, 10153-10192.

Ishii, T. (1975), The relation between temperature and composition of pigeonite in some lavas and their application to geothermometry. Mineral. J., 8, 48-57.

Kawano, Y. and Yagi, K. and Aokj, K. (1961), Petrography and petrochemistry of the vol. canic rocks of Quaternary volcanoes of northeastern Japan. Sci. Rep., Tohoku Univ, Ser. III, 7, 1-48.

Koga, S. (1984), Geology and petrology of Akagi volcano, Gunma Prefecture, Japan. Sci. Rsp., Inst. Geosci., Univ. Tsukuba, 5, 1-67.

Kuno, H. (1950), Petrology of Hakone volcano and the adjacent areas, Japan. Bull. Geol Soc. Amer, 61, 957-1020.

Kuno, H. (1959), Origin of Cenozoic petrographic provinces of Japan and surrounding areas. Bull. Volcanol. Ser. II, 20, 37-76.

Kuno, H. (1966), Lateral variation of basaltic magma type across continental margins and island arcs. Bull. Volcanol, 29, 195-222.

Kushiro, I. (1969), The system forsterite-diopsidesilica with and without water at high pressure. Amer. J. Sci., 267A, 269-294.

Matsumoto, R. and Urabe, T. (1980), An automatic analysis of major elements in silicate rocks with $X$-ray fluorescence spectrometer using fused disc samples. J. Japan. Assoc. Min. Petr. 
Econ. Geol., 75, 272-278 (in Japanese with English abstract).

Moriya, 1. (1968), Geomorphology and geology of Akagi volcano. Maebashi forestry bureau. 65 pp. (in Japanese).

Moriya, I. (1970), History of Akagi volcano. Bull. Volcanol. Soc. Japan, 15, 120 131.

Nakamura, Y. and Kushiro, I., (1970a), Compositional relations of coexisting orthopyroxene, pigeonite and augite in a tholeiitic andesite from Hakone volcano. Contrib. Mineral. Petrol., 26, 265- 275.

Nakamura, Y. and Kushiro, I. (1970b), Equilibrium relations of hypersthene, pigeonite and augite in crystallizing magmas: microprobe study of a pigeonite andesite from Weiselberg, Germany. Amer. Mineral., 55, 1999-2015.

Osbom, E.F. (1959), Role of oxygen pressure in the crystallization and differentiation of basaltic magma. Amer. J. Sci., 257, 609-647.

Osborn, E.F. (1969), The complementariness of orogenic andesite and alpine peridotite. Geochim. Cosmochim. Acta, 33, 307-324.

Osborn, E.F. and Watson, E.B. (1977), Studies of phase relations in subalkaline volcanic rock series. Carnegie Inst. Washington, Year Book, 76, 472-478.

Osborn, E.F., Watson, E.B. and Rawson, S.A. (1979), Composition of magnetite in subalkaline volcanic rocks. Camegie Inst. Washington, Year Book, 78, 475-481.

Ota, R. (1952), Petrographic study on the Akagi volcano lava. Geol. Surv. Japan, Rept., no. 151, 1-40 (in Japanese).

Ota, R. (1953), Geological map "Numata" and explanatory text of the geological map of Japan. Geol. Surv. Japan, 37 pp. (in Japanese with English abstract).

Piwinskii, A.J. (1973), Experimental studies of igneous rock series, central Sierra Nevada batholith, California: Part II. N. Jb. Mineral. Mh., H. 5, 193-215.
Roeder, P.I. and Emslie, R.F. (1970), Olivine-liquid equilibrium. Contrib. Mineral. Petrol., 29, $275-289$

Sakuyama, M. (1979), Evidence of magma mixing : petrological study of Shirouma-Oike calcalkaline andesite volcano, Japan. J. Vol. canol. Geotherm. Res., 5, 197-208.

Sakuyama, M. (1981), Petrological study of the Myoko and Kurohime volcanoes, Japan : crystallization sequence and evidence for magma mixing. J. Petrol., 22, 553-583.

Sakuyama, M. (1983), Petrology of arc volcanic rocks and their origin by mantle diapir. J. Volcanol. Geotherm. Res., 18, 297-320.

Sekine, T., Katsura, T. and Aramaki, S. (1979), Water saturated phase relations of some andesites with application to the estimation of the initial temperatures and water pressure at the time of eruption. Geochim. Cosmochim. Acta, 43, 1367-1376.

Spencer, K.J. and Lindsley, D.H. (1981), A solution model for coexisting iron-titanium oxides. Amer. Mineral., 66, 1187-1201.

Wells, P.R.A. (1977), Pyroxene thermometry in simple and complex systems. Conirib. Min. eval. Petrol., 62, 129-139.

Yamaguchi, T. (1981), Geology of Hotaka volcano. J. Geol. Soc Japan, 87, 823-832 (in Japanese with English abstract).

Yamaguchi, T. (1984), Fractional crystallization of the island arc tholeitic magma in Hotaka volcano. J. Japan. Assoc. Min. Petr. Econ. Geol., 79, 214-232.

Yoder, H.S., Jr. (1965), Diopside anorthite water at five and ten kilobars and its bearing on explosive volcanism. Camegie Inst. Washington, Year Book, 64, 82-89.

Yoder, H.S., Jr. and Tilley, C.E. (1962), Origin of basalt magmas: An experimental study of natural and synthetic rock systems. $J$. Petrol., $3,342-532$. 


\title{
武尊, 赫城火山の比較岩石学
}

\author{
山口. 尚志
}

武尊火山と赤城火山のマグマは、マグマ溜りに批ける結䐯分化の道すじに括いていくつかの異ならた点 がある。赤城火山において見積もられたマグマの温度は, $\mathrm{SiO}_{2} \quad 54$ から $70 \mathrm{wt} \%$ の液組成の变化の間 $1050^{\circ} \mathrm{C}$ 加 $920^{\circ} \mathrm{C}$ 一約 $130^{\circ} \mathrm{C}$ 低下するが, 武尊火山に招いて哇, 同し液組成変化の間化 $1050^{\circ} \mathrm{C}$ 加 $990^{\circ} \mathrm{C}$ へ約 $60^{\circ} \mathrm{C}$ 犬゙け低下する。又，赤城火山マグマのフルミナ量は武尊火山マダマに比べて多い。これらの相違 は，赤城火山の親マダ、の水分量が武尊火山の親マダマの水分量に比べて多いといらことを示している。 赤城火山のマグマの $\mathrm{FeO}^{*} / \mathrm{MgO}$ は $\mathrm{SiO}_{2}$ の增加に対して质とんと変化しないのに対し, 武尊火山のマグ マでは $\mathrm{FeO}^{*} / \mathrm{MgO}$ が增加する。晶出結晶量の計算はこの違いが斜長石の晶出量比と関係していることを 示崚している。 